\title{
Effect of active packaging on sensory attributes of low sugar, low calorie and fibre enriched Lal Peda
}

\author{
B. C. ANDHARE, D. C. RAI AND TANWEER ALAM
}

\begin{abstract}
Varanasi, the city of gallis and ghats is not only famous for its Banarasi saree and Banarasi paan, but also famous for the Lal Peda loaded with higher amount of sugar and loaded with Ghee, the Peda is shaped by hand and dusted with semolina and pistachios as a finishing touch. Lal Peda is a popular heat desiccated traditional dairy delicacy of eastern India specially Uttar Pradesh. It is prepared by blending of Khoa and sugar followed by heat desiccation until characteristic reddish brown colour appears. The Lal Peda is deficit in fibre so the developed Lal Peda was prepared with addition of oat. This product is manufactured since long time yet not glamorized as other Khoa based sweet products like Burfi, Peda etc. The main reason behind this is, these products centered into specific areas and have not proper focused by research scientists and extension workers. So the experiment was carried out on low calorie, low sugar and fibre enriched Lal Peda. The Lal Peda samples packed in polythene bags coated with nisin as a bio-preservative to check the preservation ability of the developed Lal Peda. The Lal Peda samples were packed in commercial Nasco sampling polyethylene bags using MAP equipment Reepack $®$ and MAP mix 9000 Gas mixer, manufactured by PBI DAN5SENSOR A/S, Ringstead, Denmark. Three different combinations of gases i.e. 75 per cent $\mathrm{CO}_{2} 25$ per cent $\mathrm{N}_{2}, 50$ per cent $\mathrm{CO}_{2:} 50$ per cent $\mathrm{N}_{2}$ and 25 per cent $\mathrm{CO}_{2:} 75$ per cent $\mathrm{N}_{2}$ were used to pack the Lal Peda samples. The samples packed under air were kept as control. The samples were stored in a BOD incubator (Remi Elektrotechnik Ltd., New Delhi, India) at 20 and $37^{\circ} \mathrm{C}$ and were analyzed for sensory attributes at an interval of 10 days. The sensory evaluation was carried out by 10 semi expert judges.
\end{abstract}

KEY WORDS : Low sugar, Low calorie, Fibre, Lal Peda, Active packaging

HOW TO CITE THIS PAPER : Andhare, B.C., Rai, D.C. and Alam, Tanweer (2016).Effect of active packaging on sensory attributes of low sugar, low calorie and fibre enriched Lal Peda. Res. J. Animal Hus. \& Dairy Sci., 7(2) : 61-67 : DOI: 10.15740/HAS/RJAHDS/7.2/61-67.

\section{MEMBERS OF RESEARCH FORUM}

Address for correspondence :

B.C. Andhare, College of Agriculture, Badnapur, JALNA (M.S.) INDIA

Email : andharebcshree@gmail.com

Associated Authors' :

D.C. Rai, Banaras Hindu University, VARANASI (U.P.) INDIA

Tanweer Alam, Indian Institute of Packaging, NEW DELHI, INDIA 